\title{
Determination of the freshwater origin of Coastal Oyashio Water using humic-like fluorescence in dissolved organic matter
}

\author{
Yu Mizuno ${ }^{1}$ Jun Nishioka ${ }^{1,2} \cdot$ Takahiro Tanaka $^{3} \cdot$ Yuya Tada $^{4,5} \cdot$ Koji Suzuki $^{1,5} \cdot$ Yuta Tsuzuki $^{1} \cdot$ Atsuko Sugimoto $^{1,6}$. \\ Youhei Yamashita ${ }^{1,5}$
}

Received: 6 November 2017 / Revised: 20 April 2018 / Accepted: 21 April 2018 / Published online: 9 May 2018

(c) The Author(s) 2018

\begin{abstract}
Coastal Oyashio Water (COW), defined as a water mass with a temperature lower than $2{ }^{\circ} \mathrm{C}$ and a salinity lower than 33.0 , is distributed in the North Pacific Ocean off southeastern Hokkaido, Japan, from winter to spring. COW is rich in macronutrients and dissolved iron and is thus considered to affect the spring phytoplankton blooms in the Oyashio region. Although river water and sea-ice melt water have been considered freshwater end-members of COW, the contributions of these freshwater sources to COW have not been well described. In this study, the humic-like components in dissolved organic matter were first applied as a parameter to evaluate the freshwater end-members of COW in March 2015. Linear regressions with negative slopes were determined between the humic-like components and the salinity of COW. The intercepts of the regressions against the humic-like components were within the ranges of those observed for the local rivers of Hokkaido but were very different from those of sea ice. These findings suggest that river water contributed to the COW observed here as a freshwater end-member, although the contribution of sea-ice melt water to COW could not be evaluated. This novel approach also highlighted two different less-saline water masses in COW. The first was characterized by a lower temperature and relatively high levels of humic-like components, while the second was higher in temperature and had higher levels of humic-like components. It is suggested that these different characteristics are due to the contributions of water from different rivers and/or different effects of sea-ice melt water.
\end{abstract}

Keywords Coastal Oyashio Water · Freshwater end-member · River water · Sea-ice melt water · Dissolved organic matter · Humic fluorescence

Youhei Yamashita

yamashiy@ees.hokudai.ac.jp

1 Graduate School of Environmental Science, Hokkaido University, Sapporo, Japan

2 Pan-Okhotsk Research Center, Institute of Low Temperature Science, Hokkaido University, Sapporo, Japan

3 Tohoku National Fisheries Research Institute, Fisheries Research and Education Agency Japan, Shiogama, Japan

4 Environmental Chemistry Section, National Institute for Minamata Disease, Minamata, Japan

5 Faculty of Environmental Earth Science, Hokkaido University, Sapporo, Japan

6 Arctic Research Center, Hokkaido University, Sapporo, Japan

\section{Introduction}

Riverine humic substances can be considered one of the major components of dissolved organic matter (DOM) in coastal environments because linear negative correlations between the salinity and dissolved organic carbon (DOC) concentration as well as the fluorescence derived from terrestrial humic substances have often been observed (Fellman et al. 2010; Yamashita et al. 2011; 2015a; Cao et al. 2016). These negative correlations also suggest that the fluorescence intensity of terrestrial humic substances (in other words, the levels of terrestrial humic fluorophores) can be used as a tracer of river water, similar to the oxygen isotopes of water or alkalinity (e.g., Yamamoto-Kawai et al. 2009). However, it should be noted that marine organisms, in particular bacteria, produce humic-like fluorophores (e.g., Romera-Castillo et al. 2011; Goto et al. 2017; Arai et al. 2018), sunlight degrades humic-like fluorophores 
(e.g., Moran et al. 2000; Vähätalo and Wetzel 2004), and the levels of humic-like fluorophores in river water show temporal variability (e.g., Austnes et al. 2010; Chen et al. 2013; Walker et al. 2013). Thus, the relationship between salinity and humic-like fluorophores has generally been used to evaluate the abovementioned environmental dynamics of humic fluorophores (including autochthonous humic-like fluorophores), rather than to trace the river water in coastal environments (e.g., Vodacek et al. 1997; Yamashita et al. 2008; Cawley et al. 2014; Maie et al. 2014).

Chen and Gardner (2004) observed conservative mixing of humic fluorophores between various freshwater and marine end-members with significant in situ microbial production, evidence of flocculation, and minor photobleaching effects in the Mississippi and Atchafalaya river plume regions using in situ fluorescence sensors. Previous studies carried out in the Arctic Ocean have indicated that humiclike fluorophores can be used to trace river water (Amon et al. 2003; Walker et al. 2009; Gonçalves-Araujo et al. 2016) and to separate the distributions of two different freshwater sources, i.e., river water and sea-ice melt water, because the levels of humic-like fluorophores in river and sea-ice melt water are very different (Gonçalves-Araujo et al. 2016; Tanaka et al. 2016). The abovementioned studies imply that freshwater end-members can be specified and traced using humic-like fluorophores in combination with salinity, oxygen isotopes of water, or alkalinity in particular environments in coastal regions, such as a region where several freshwater sources with different levels of humic-like fluorophores make contributions to the coastal waters and where the photobleaching effect is low. However, at present, humic-like fluorophores have scarcely been applied to identify freshwater end-members in coastal environments.

The coastal region of southeastern Hokkaido, the northern island of Japan, is affected by the Oyashio Current. The Oyashio Current flows southwestward along the slope as a western boundary current of the subarctic gyre (Qiu 2001). Two typical water masses are seasonally present on the shelf of southeastern Hokkaido. The Modified Soya Warm Current Water (SWCW) derives from the Sea of Japan via the Sea of Okhotsk and strengthens from summer to autumn (Kono 1997; Isoda et al. 2003; Oguma et al. 2008). From winter to spring, the Coastal Oyashio Water (COW), defined as a water mass with a temperature lower than $2{ }^{\circ} \mathrm{C}$ and a salinity lower than 33.0 (Ohtani 1971; Hanawa and Mitsudera 1986), is widely distributed (Isoda et al. 2003; Kono et al. 2004; Oguma et al. 2008). COW can also be characterized as rich in dissolved iron in addition to macronutrients (Nakayama et al. 2010; Nishioka et al. 2011), and it possibly induces spring phytoplankton blooms in the Oyashio region (Kono and Sato 2010; Nakayama et al. 2010), where bloomforming, microplankton-sized diatoms can be stressed by iron availability (Hattori-Saito et al. 2010). It has also been reported that spring diatom blooms in the region usually end by June or July due to the limited iron availability (Saito et al. 2002).

Three distinct sources have been proposed as freshwater end-members of COW. Ohtani $(1971,1989)$ pointed out that sea-ice melt water is an important freshwater end-member of COW. Other researchers (Isoda et al. 2003; Oguma et al. 2008; Kusaka et al. 2009) indicated a contribution of Eastern Sakhalin Current Water, which is affected by the Amur River (Mizuta et al. 2003), to COW. A contribution from local rivers in eastern Hokkaido to COW was also suggested (Oguma et al. 2007, 2008). However, spatiotemporal variability in the distribution of these freshwater end-members of COW has not been well documented.

In the study reported in the present paper, the spatial distributions of humic-like fluorophores were observed in the coastal region off southeastern Hokkaido in March 2015. The goal of this study was to determine the major freshwater end-members of COW during the observations. Water from various rivers in Hokkaido, estuarine water from the Amur River, and sea ice from the Sea of Okhotsk were used as freshwater end-members. Negative correlations between salinity and humic-like fluorophores are usually observed in coastal environments, as mentioned above, indicating that the levels of humic-like fluorophores in riverine end-members are higher than those in marine end-members in coastal environments. It is well established that levels of humiclike fluorophores in sea-ice melt water are low compared to seawater due to drainage with brine rejection during sea-ice formation (Stedmon et al. 2007, 2011; Müller et al. 2013). Therefore, to evaluate the major freshwater end-members of COW, it is important to assess the relationship between salinity and humic-like fluorophores.

\section{Materials and methods}

\subsection{Observations and sample collection in COW and the Oyashio region}

Observations of the Oyashio region, covering the COW, were carried out in March 2015 during a cruise on the R/V Hakuho Maru KH-15-1 (Fig. 1). An observation transect was followed along the "A-line" from off Akkeshi to southeast Hokkaido, Japan. Station A1 was observed 7 times from the 9th to the 20th (JST) during the cruise. The sampling dates for the other stations were as follows: 8th (station A0), 9th (station A2), 14th (station A3), 15th (station A4), 16th (stations A11 and A8), 17th (station A6), and 18th (station A5). In addition to the A-line, observations were carried out at eight stations in the region.

Seawater samples were generally collected from the surface to the bottom or $250 \mathrm{~m}$ using a 


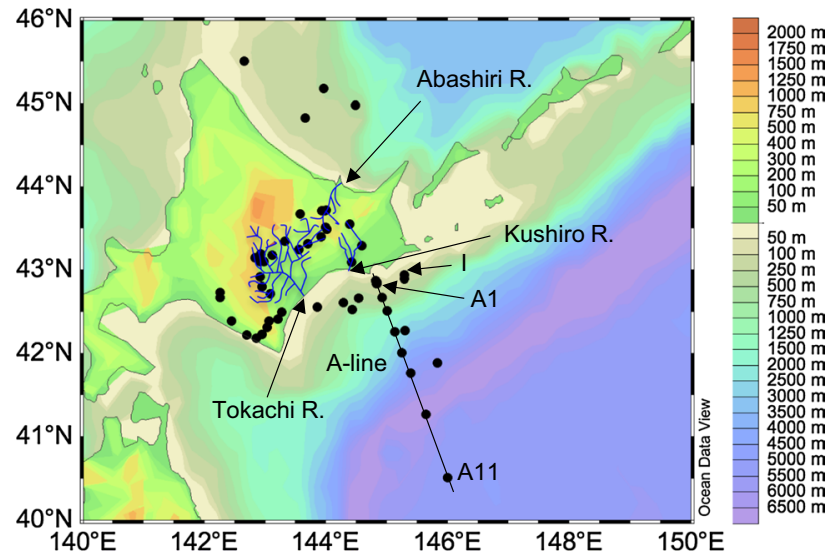

Fig. 1 Map of the sampling locations for seawater samples in the Oyashio region of the western North Pacific Ocean (including the Coastal Oyashio Water), sea-ice samples in the southern Sea of Okhotsk, and river water samples in Hokkaido, Japan. Major rivers for river water sampling (the Tokachi, Kushiro, and Abashiri rivers) are drawn in Hokkaido

conductivity-temperature-depth (CTD)-carousel multiple sampling (CMS) system (SBE-911plus and SBE-32 water samplers, Sea Bird Electronics, Inc.) equipped with acidcleaned Niskin-X bottles. Samples were collected from the surface to $\sim 5000 \mathrm{~m}$ at some stations. An acid-cleaned $0.22 \mu \mathrm{m}$ Durapore filter (Millipak, Millipore) was attached directly to the spigot of the Niskin bottles, and seawater was gravity filtered into a precombusted glass vial with an acid-cleaned Teflon-lined cap after triple rinsing. The samples were then stored frozen in the dark until analysis (4-16 months). The temperature and salinity used in this study were collected by the CTD sensors. Chlorophyll $a$ concentrations were determined with the fluorometric method of Welschmeyer (1994).

The current velocity data at station A1 were obtained by a vessel-mounted acoustic Doppler current profiler (ADCP) at 10-min intervals (Teledyne RD Instruments, broadband $76.8 \mathrm{kHz}$ ). After correcting the misalignment of the ADCP (Joyce 1989) and removing erroneous data whose percent good derived from the ADCP data was less than 80 as well as those obtained when the ship was accelerating, we obtained a velocity profile of each cast by temporally averaging the data during the cast.

\subsection{Collection of sea-ice samples}

Four sea-ice blocks were collected with a basket suspended from the ship's crane over the ice surface in the southern Sea of Okhotsk (Fig. 1) during cruises aboard the icebreaker P/V Soya in February 2012, February 2013, and February 2014, according to Kanna et al. (2014). The sea-ice blocks were placed in double plastic bags and then stored frozen in the dark. In the onshore laboratory, a sea-ice block was broken into small pieces with an icepick and a ceramic knife, and small pieces were placed into an acid-cleaned Teflon beaker and melted in the dark at room temperature. Immediately after melting, the sea-ice melt water was filtered through a $0.22 \mu \mathrm{m}$ filter (Durapore, Millipore) under a gentle vacuum, collected in precombusted glass vials with acid-cleaned, Teflon-lined caps after triple rinsing, and then stored at $-20{ }^{\circ} \mathrm{C}$ for 2 days until analysis. The salinity of the sea-ice samples was measured by an automatic salt/chloride analyzer (model SAT-210, Towa Electronic Industry) with a conversion factor for salinity, according to Kanna et al. (2014).

\subsection{Collection of a sample in the estuary of the Amur River}

One estuarine sample was collected at a station in the vicinity of the mouth of the Amur River $\left(53.45^{\circ} \mathrm{E}, 142.00^{\circ} \mathrm{N}\right)$ on 8 September 2006 by the R/V Professor Khromov (Far Eastern Hydrometeorological Research Institute: FERHRI). The sampling procedure is described here only briefly, but is described in detail elsewhere (Nishioka et al. 2014). Surface water $(2 \mathrm{~m})$ was collected by the CTD-CMS system equipped with acid-cleaned Niskin-X bottles, filtered through a $0.22 \mu \mathrm{m}$ Durapore filter (Millipak, Millipore), collected in an acid-cleaned FLPE bottle, and then stored frozen in the dark until analysis. The temperature and salinity used in this study were collected by the CTD sensors.

\subsection{Collection of river water samples in Hokkaido, Japan}

Observations of 33 rivers located in the southern and eastern parts of Hokkaido, Japan, were carried out on 18-20 September 2011. The hydrographs of the rivers during sampling could be characterized as base flow. The rivers consisted of small streams to the middle and lower reaches of relatively large rivers, such as the Tokachi, Kushiro, and Abashiri rivers. The upper reaches of the relatively large rivers are generally covered with forests (Woli et al. 2008; Muneoka et al. 2012). The middle reaches of the Tokachi and Abashiri rivers are covered with agricultural areas (Woli et al. 2008; Muneoka et al. 2012). The lower reaches of the Kushiro River flow through the Kushiro Mire (Ahn et al. 2008). Thus, the rivers observed in this study cover various types of watersheds: forests, agricultural areas, and wetlands. It is well established that the quantity and quality of DOM in river water are dependent on the watershed environment (e.g., Stedmon et al. 2003; Williams et al. 2010). As such, it can be expected that the riverine DOM observed in this study will show wide variability in quantity and quality due to the range of watershed environments.

River water samples were collected from the center of a bridge using a bucket that had been rinsed three times. The 
water sample was immediately filtered through a $0.45 \mu \mathrm{m}$ filter (Durapore, Millipore) with an acid-cleaned plastic syringe, collected into an acid-cleaned polypropylene bottle, and then stored in a cooler and a refrigerator until analysis. Chemical analyses were carried out within 5 days after sample collection.

Daily discharge data for the local rivers in Hokkaido were obtained through the Water Information System provided by the Ministry of Land, Infrastructure, Transport and Tourism (http://www1.river.go.jp/).

\subsection{Excitation-emission matrix fluorescence and parallel factor analysis}

Excitation-emission matrix (EEM) fluorescence was determined using a fluorometer (FluoroMax-4, Horiba) according to Tanaka et al. (2014). The frozen samples of seawater, seaice melt water, and estuarine water were thawed and allowed to stand until they reached close to room temperature before the EEM measurements. The cooled river water samples were also allowed to stand until they reached near to room temperature before the EEM measurements. Emission scans from 290 to $550 \mathrm{~nm}$ taken at 2-nm intervals were acquired in the $S / R$ mode for excitation wavelengths between 250 and $450 \mathrm{~nm}$ at $5-\mathrm{nm}$ intervals. The bandpass was set to $5 \mathrm{~nm}$ for both excitation and emission. The fluorescence spectra were scanned with a 0.1-s integration time for river water and a 0.25 -s integration time for seawater, sea-ice melt water, and estuarine water.

To correct the EEM data, inner-filter correction was carried out using the absorbance spectra (McKnight et al. 2001) determined on a spectrophotometer (UV-1800, Shimadzu) according to Yamashita et al. (2013). Quartz-windowed cells with path lengths of 1 and $5 \mathrm{~cm}$ were used for the absorbance analysis of river water and other samples (seawater, sea-ice melt water, and estuarine water), respectively. The EEM signal of Milli-Q water was subtracted from the sample EEM signals to eliminate the Raman scatter band. The specific instrument components were also corrected with the excitation and emission correction files supplied by the manufacturers. The fluorescence intensities in the EEMs were converted to Raman units (RU) using the area of the water Raman scatter peak at $350 \mathrm{~nm}$ excitation, which was analyzed daily (Lawaetz and Stedmon 2009).

Parallel factor analysis (PARAFAC) statistically decomposes EEMs into several fluorescent components and residues. PARAFAC modeling of EEMs has already been described in detail elsewhere (Stedmon et al. 2003; Stedmon and Bro 2008). PARAFAC analysis was conducted using MATLAB (MathWorks, Natick, MA, USA) with the DOMFluor toolbox (Stedmon and Bro 2008). The wavelength range used for PARAFAC was 250-455 and 290-520 nm for excitation and emission, respectively. Two river water samples were identified as outliers through the PARAFAC procedure, and the three-component model was validated by split-half validation and random initialization (Stedmon and Bro 2008).

\section{Results}

\subsection{Hydrographic conditions during the observations}

The spatial distributions of the temperature, salinity, and chlorophyll $a$ concentration in the upper $250 \mathrm{~m}$ layer of the A-line are shown in Fig. 2. The lowest temperature $\left(-0.2^{\circ} \mathrm{C}\right)$ and salinity $(32.2)$ were observed at station A0, and the temperatures at depths shallower than $75 \mathrm{~m}$ gradually increased towards the offshore. COW, namely, the water mass characterized by a temperature lower than $2{ }^{\circ} \mathrm{C}$ and a salinity lower than 33.0, was observed at the surface layer at stations A0 to A6 along the transect. The temperature and salinity at depths deeper than $75 \mathrm{~m}$ at onshore stations were generally low compared with those at offshore stations, while a water mass characterized by relatively high temperature and salinity was distributed between 75 and $200 \mathrm{~m}$ at station A3.

Figure 3 shows the temporal changes in the current velocity at $27 \mathrm{~m}$, the temperature, and the salinity during consecutive observations at station A1. A water mass characterized by low temperature $\left(<0{ }^{\circ} \mathrm{C}\right)$ and relatively high salinity (approximately 32.5) was distributed throughout the water column on 9 March. From 14 to 18 March, a water mass featuring a slightly higher temperature $\left(\sim 1^{\circ} \mathrm{C}\right)$ and a lower salinity $(<32.4)$ was distributed in the surface layer. A water mass other than the COW was distributed in the water column deeper than $16 \mathrm{~m}$ on 14 March. The temperature and salinity were relatively uniform throughout the water column from 19 to 20 March $\left(0.8-1.2\right.$ and $32.7-32.9{ }^{\circ} \mathrm{C}$, respectively). The current direction did not change much during consecutive observations and was generally comparable to the climatological mean seasonal flow for the coastal region of south Hokkaido (Rosa et al. 2007). However, a low-pressure system developed during the cruise and passed over Hokkaido from south to north from 10 to 11 March 2015; thus, the low-pressure system may have led to significant changes in temperature and salinity at station A01 between 9 and 14 March.

The discharge from local rivers in eastern Hokkaido during winter (January-February) 2015 seemed typical, while the discharge during the first half of March 2015 appeared to be relatively high compared with that in other years. For example, at an observational station along the lower reaches of the Tokachi River (Moiwa), the average discharge in February $2015\left(100 \pm 3 \mathrm{~m}^{3} \mathrm{~s}^{-1}\right)$ was comparable to the range 
Fig. 2a-c Spatial distributions of temperature (a), salinity (b), and the chlorophyll $a$ concentration (c) in the upper $250 \mathrm{~m}$ layer of the A-line
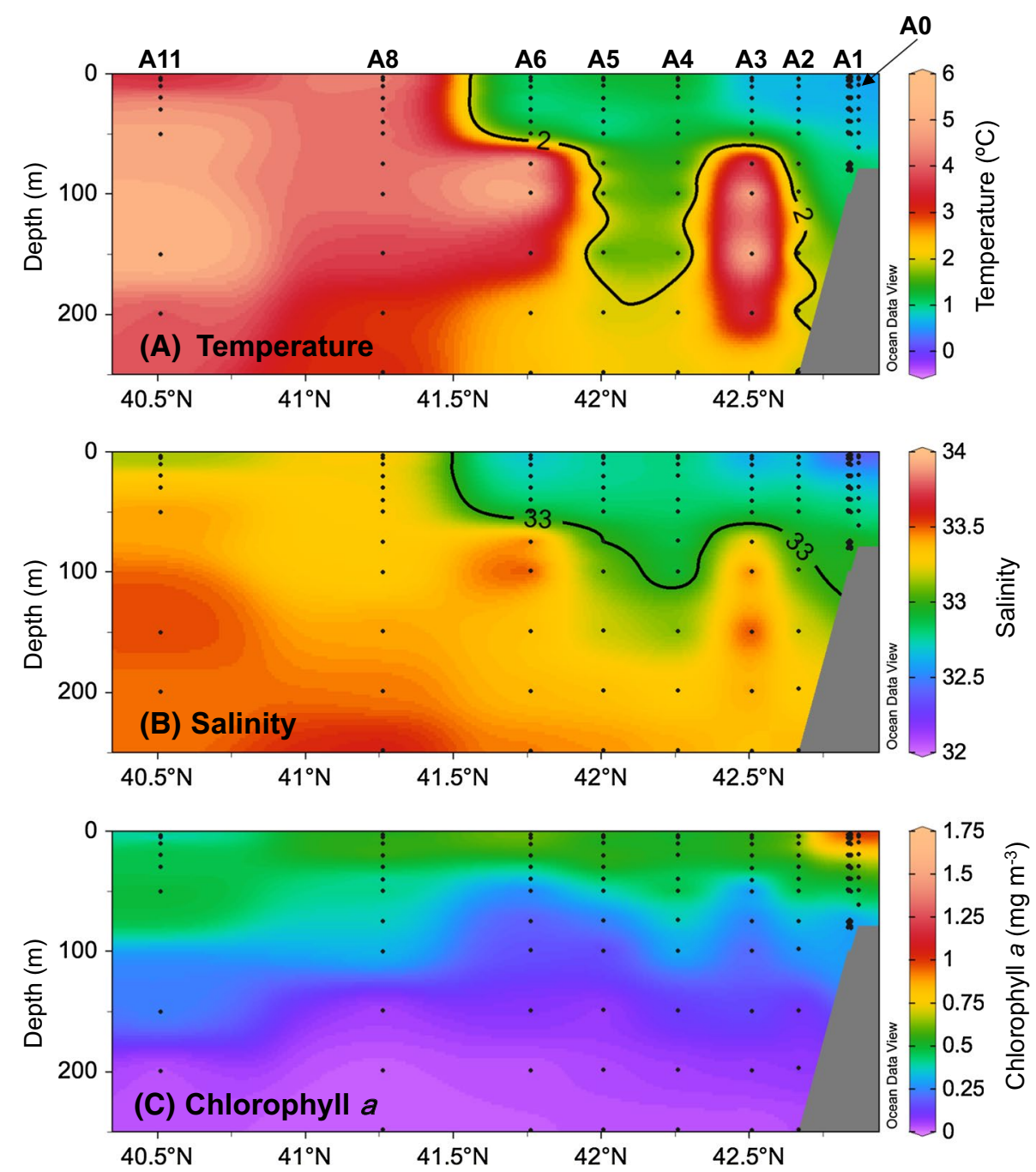

observed in the 10 years preceding $2015\left(104 \pm 10 \mathrm{~m}^{3} \mathrm{~s}^{-1}\right.$ in $2005,101 \pm 17 \mathrm{~m}^{3} \mathrm{~s}^{-1}$ in $2006,109 \pm 13 \mathrm{~m}^{3} \mathrm{~s}^{-1}$ in 2007 , $95 \pm 6 \mathrm{~m}^{3} \mathrm{~s}^{-1}$ in $2008,80 \pm 7 \mathrm{~m}^{3} \mathrm{~s}^{-1}$ in $2009,104 \pm 12 \mathrm{~m}^{3} \mathrm{~s}^{-1}$ in $2010,124 \pm 13 \mathrm{~m}^{3} \mathrm{~s}^{-1}$ in $2011,114 \pm 10 \mathrm{~m}^{3} \mathrm{~s}^{-1}$ in 2012 , $137 \pm 22 \mathrm{~m}^{3} \mathrm{~s}^{-1}$ in 2013, and $124 \pm 11 \mathrm{~m}^{3} \mathrm{~s}^{-1}$ in 2014). However, the average discharge from 1 to 15 March 2015 $\left(143 \pm 54 \mathrm{~m}^{3} \mathrm{~s}^{-1}\right)$ at the Moiwa station was higher than that during the same period in 2005-2014 (from $93 \pm 7 \mathrm{~m}^{3} \mathrm{~s}^{-1}$ in 2005 to $119 \pm 5 \mathrm{~m}^{3} \mathrm{~s}^{-1}$ in 2013).

Figure 4 shows a temperature-salinity $(T-S)$ diagram for the seawater samples collected from the upper $250 \mathrm{~m}$ at all stations. Approximately $60 \%$ of the samples collected were characterized as COW. According to Nakayama et al. (2010), samples corresponding to a relatively high temperature and salinity could be characterized as modified Kuroshio Water (MKW), which detaches from the Kuroshio Extension (Yasuda et al. 1992). Other samples could be categorized as Oyashio Water (OYW).

The chlorophyll $a$ concentration ranged from 0.01 to $4.01 \mathrm{mg} \mathrm{m}^{-3}$ in this study. Levels of chlorophyll $a$ along the
A-line were generally high in the surface layer and decreased with depth (Fig. 2). Higher levels $\left(1.0-1.5 \mathrm{mg} \mathrm{m}^{-3}\right.$ ) of chlorophyll $a$ along the A-line were observed at onshore stations (i.e., A0 and A1), and the highest levels seen in this study $\left(3.4-4.0 \mathrm{mg} \mathrm{m}^{-3}\right)$ were observed at station I located at $145.29^{\circ} \mathrm{E}, 42.93^{\circ} \mathrm{N}$. The chlorophyll $a$ concentration observed in this study generally corresponded to prebloom periods because a long-term observation carried out from 1990 to 1998 found that the chlorophyll $a$ concentration in the spring bloom of the Oyashio region ranged from 2.2 to $12.8 \mathrm{mg} \mathrm{m}^{-3}$, with a mean \pm 1 standard error of $5.67 \pm 3.6 \mathrm{mg} \mathrm{m}^{-3}$ (Saito et al. 2002).

\subsection{EEM-PARAFAC}

A three-component model was validated based on the PARAFAC modeling of four EEMs of sea-ice melt water, 31 EEMs of river water in Hokkaido, one EEM of estuary water from the Amur River, and 290 EEMs of seawater (Fig. 5), implying that the EEM of the dataset exhibited relatively 
Fig. 3a-c Temporal variability in the current velocity at $27 \mathrm{~m}$ (a), the temperature (b), and the salinity (c) during seven observations from 9 to 20 March (JST) at station A1
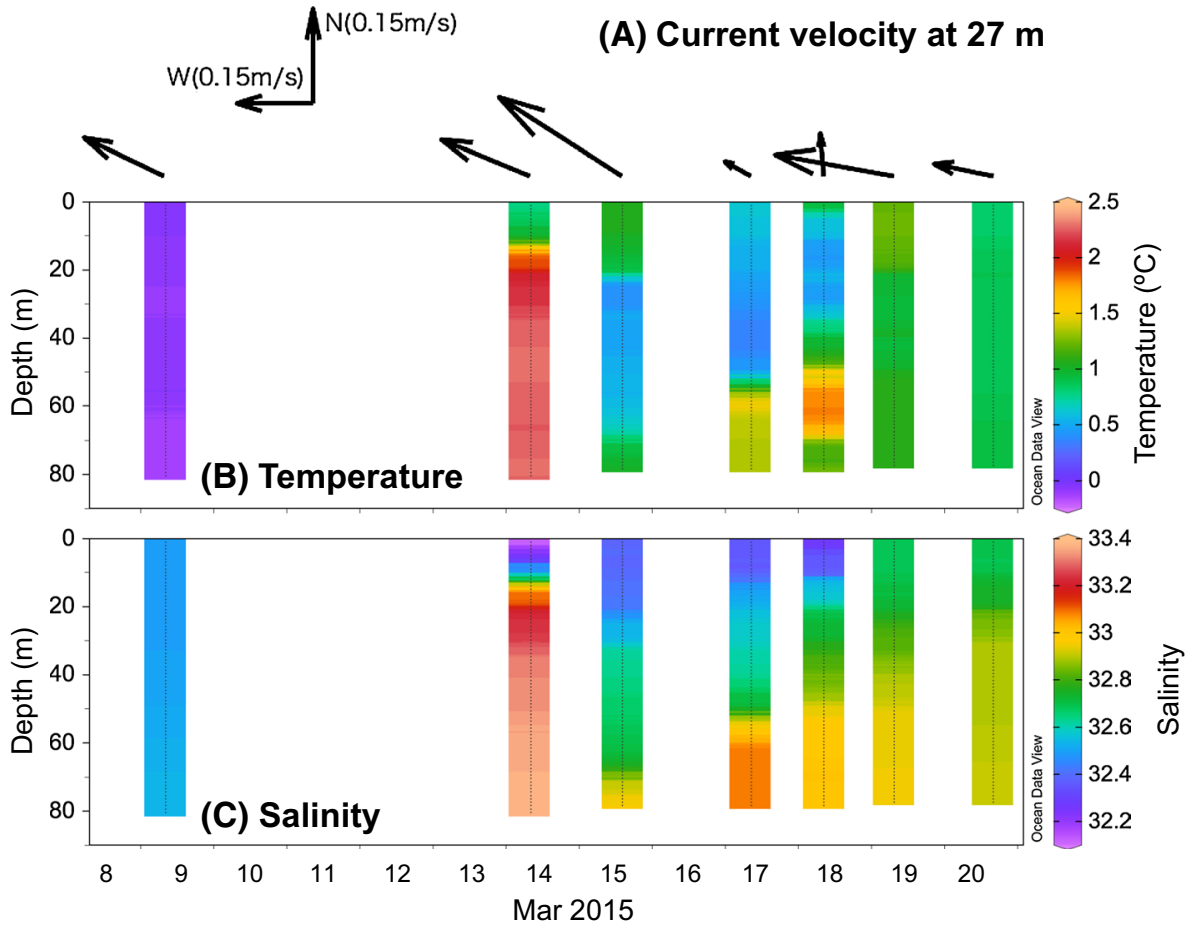

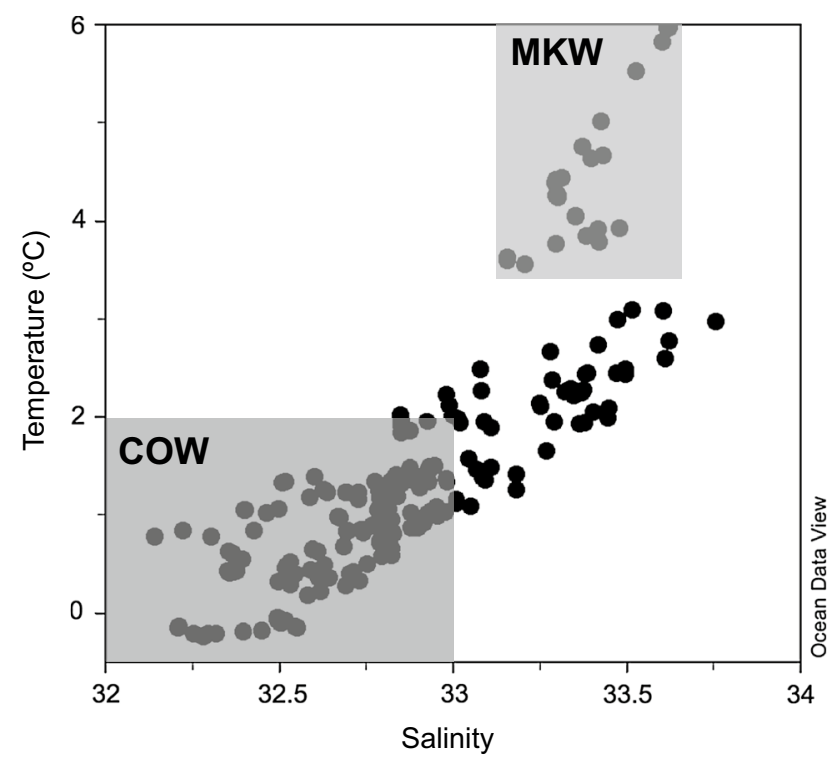

Fig. 4 Temperature-salinity $(T-S)$ diagram for seawater samples collected from the upper $250 \mathrm{~m}$ at all stations included in this study. The shaded locations correspond to the Coastal Oyashio Water (COW) and the modified Kuroshio Water (MKW)

small variations. Component $1(\mathrm{C} 1)$ produced peaks at an emission wavelength of $480 \mathrm{~nm}$ from excitation wavelengths of $<250$ and $350 \mathrm{~nm}$. This component could be categorized as a humic-like fluorophore that is traditionally defined as terrestrial (Coble 1996). Component 2 (C2) could also be designated a humic-like fluorophore that is traditionally defined as marine because this component produced peaks at an emission wavelength of $398 \mathrm{~nm}$ from excitation wavelengths of $<250$ and $315 \mathrm{~nm}$ (Coble 1996). In contrast, a peak produced at an emission wavelength of $334 \mathrm{~nm}$ from an excitation wavelength of $280 \mathrm{~nm}$ by component 3 (C3) represented a protein-like fluorophore, in particular a tryptophan molecule (Coble 1996; Yamashita and Tanoue 2003).

\subsection{PARAFAC components in COW and the Oyashio region}

The spatial distributions of the fluorescence intensities of individual PARAFAC components along the A-line are shown in Fig. 6. The distribution pattern of humic-like $\mathrm{C} 1$ is similar to that of humic-like $\mathrm{C} 2$. High levels of these humiclike components were generally found in the upper layer at onshore stations (A0 and A1) and in the water column deeper than $200 \mathrm{~m}$. Low levels of humic-like components were evident in the water column shallower than $100 \mathrm{~m}$ at offshore stations (A6, A8, and A11) and at 75-200 m at station A3. Low levels of humic-like components corresponded to water masses characterized by high temperatures (Figs. 2, $6)$.

The spatial distribution of protein-like $\mathrm{C} 3$ was somewhat different from those of humic-like $\mathrm{C} 1$ and $\mathrm{C} 2$ (Fig. 6). The levels of protein-like $\mathrm{C} 3$ were generally high in the surface layers and decreased with depth, irrespective of the differences in the stations. In the surface layers, particularly high levels were evident at the onshore stations (A0 and A1). 

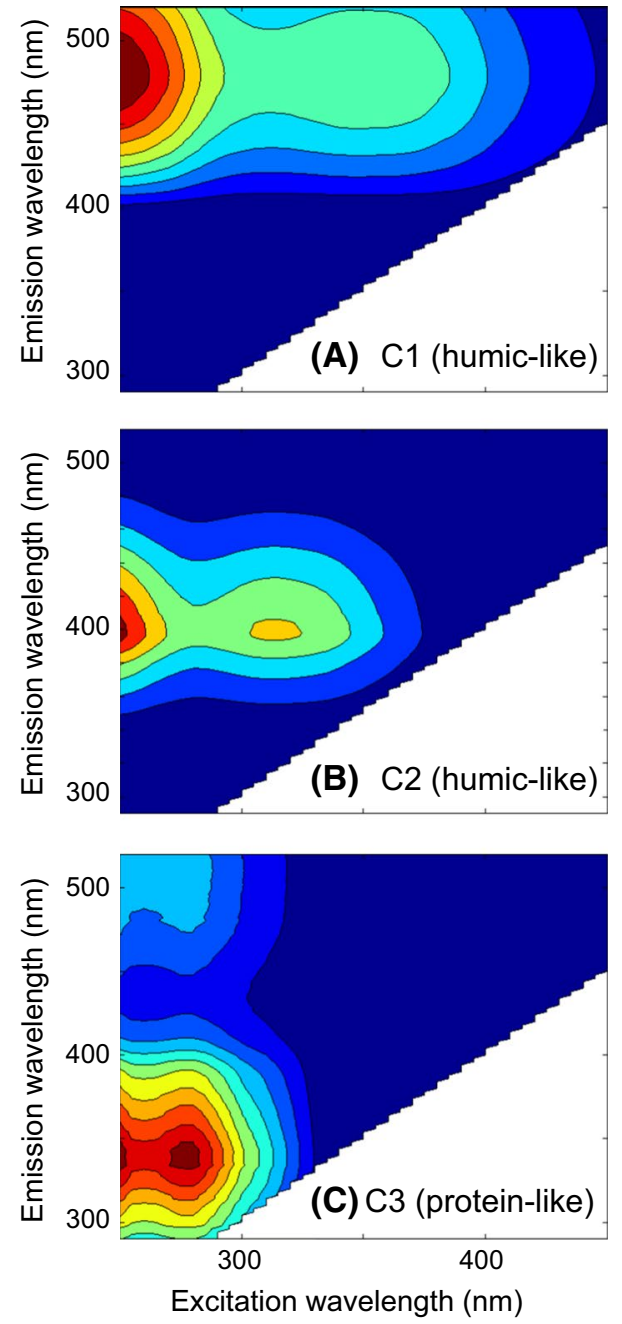

Fig. 5a-c Excitation-emission matrices for three PARAFAC components: humic-like $\mathrm{C} 1$ (a), humic-like $\mathrm{C} 2$ (b), and protein-like $\mathrm{C} 3$ (c)

This distribution pattern of the protein-like component was similar to that of the chlorophyll $a$ concentration (Figs. 2, 6).

Scatter plots between each PARAFAC component and salinity as well as the chlorophyll $a$ concentration, with temperature on the $z$-axis, were determined for the COW observed in this study (Fig. 7). Negative linear relationships were evident between three PARAFAC components and salinity: $[\mathrm{C} 1]=-0.0072 \pm 0.0006 \times[$ salinity] $+0.25 \pm 0.02, \quad R^{2}=0.49, \quad n=144, \quad p<0.001$; $[\mathrm{C} 2]=-0.0091 \pm 0.0009 \times[$ salinity $]+0.31 \pm 0.03, R^{2}=0.42$, $n=144, p<0.001$; and [C3] $=-0.0064 \pm 0.0006 \times$ [salinity] $+0.22 \pm 0.02, R^{2}=0.45, n=144, p<0.001$.

The chlorophyll $a$ concentrations were exceptionally high (3.4-4.0 $\mathrm{mg} \mathrm{m}^{-3}$ ) for four samples obtained from $0-20 \mathrm{~m}$ at station I (Figs. 1, 7). Except for these samples, the correlation of the chlorophyll $a$ concentration with protein-like C3 $(r=0.58, n=140, p<0.001)$ was better than those with humic-like $\mathrm{C} 1(r=0.29, n=140, p<0.001)$ and $\mathrm{C} 2(r=0.21$, $n=140, p<0.001)$.

\subsection{PARAFAC components in possible freshwater end-members of COW}

The fluorescence intensity of humic-like $\mathrm{C} 1$ ranged from 0.038 to 0.471 for river water, from 0.002 to 0.011 for seaice melt water, and was 0.457 for the Amur River estuarine water. The fluorescence intensity of humic-like $\mathrm{C} 2$ ranged from 0.037 to 0.500 for river water, from 0.003 to 0.012 for sea-ice melt water, and was 0.555 for the Amur River estuarine water. Among the river water sources, the highest levels of humic-like $\mathrm{C} 1$ and $\mathrm{C} 2$ were derived from the lower reaches of the Kushiro River, which flows through the Kushiro Mire. The fluorescence intensity of protein-like C3 ranged from 0.006 to 0.093 for river water, from 0.007 to 0.024 for sea-ice melt water, and was 0.124 for the Amur River estuarine water. Thus, if one compares these endmember levels with the levels found in COW (Fig. 7), the abundance of humic-like $\mathrm{C} 1$ and $\mathrm{C} 2$ was highest for river water samples (including the estuarine water sample), followed by COW, and then the sea-ice melt water samples. The levels of protein-like C3 were similar in some of the river water samples, sea-ice melt water samples, and COW, even though the estuarine water and other river water samples contained levels that were one order of magnitude higher than those in COW.

\section{Discussion}

COW was evident in the coastal region of southeastern Hokkaido during this study (Figs. 2, 3), which is typical for this region (Kusaka et al. 2009). Higher concentrations of dissolved iron were evident, corresponding to less-saline water during the A-line observations in January (Nishioka et al. 2011). Thus, the freshwater origin of COW is crucial to understanding the mechanism of iron supply and thus to clarifying the mechanisms of the induction and maintenance of spring phytoplankton blooms (in other words, the factors shaping the spatiotemporal distribution of spring phytoplankton blooms) in the Oyashio region. Two different freshwater sources, namely, river water and sea-ice melt water, have been considered the end-members of COW (Ohtani 1971, 1989; Oguma et al. 2007, 2008; Kusaka et al. 2009). Mizuta et al. (2003) indicated that the surface water of the East Sakhalin Current is characterized by less-saline East Sakhalin Current Water due to the contribution of Amur River water. It was also suggested that the local rivers of eastern Hokkaido supply freshwater to COW (Oguma et al. 2007, 2008). 
Fig. 6a-c Spatial distributions of the fluorescence intensities of humic-like C1 (a), humic-like C2 (b), and humic-like C3 (c) in the upper $250 \mathrm{~m}$ layer of the A-line
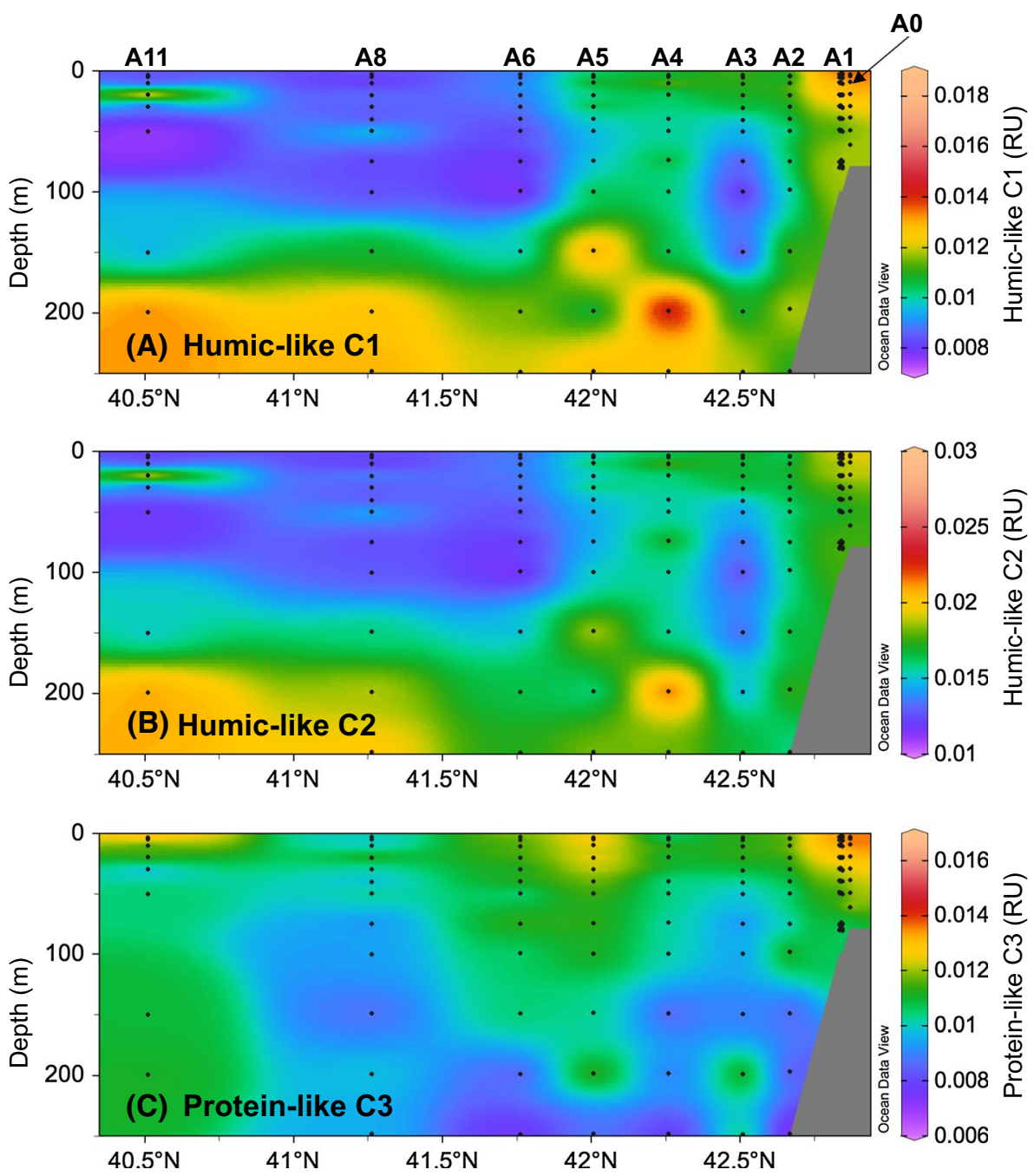

Negative linear relationships between the humic-like and protein-like components derived from EEM-PARAFAC and salinity were observed for $\mathrm{COW}$ (Fig. 7), implying that the major factor controlling the abundance of these PARAFAC components in COW was the mixing of low (and/or moderate)-salinity water with high-salinity water. More importantly, the relationships imply that these components can be useful for evaluating the freshwater end-member(s) of COW. However, it has often been observed that the abundance of protein-like PARAFAC components, in particular tryptophan-like PARAFAC components, is highest in intermediate-salinity water in some coastal environments due to the contribution of autochthonous DOM (Yamashita et al. 2008; Fellman et al. 2010, 2011). In this study, the ranges of the abundance of the protein-like component were similar among some river water samples, sea-ice melt water samples, and COW, implying that the protein-like component is produced in terrestrial aquatic environments, in sea ice, and possibly in coastal environments.
It has recently been well documented that both the traditionally defined terrestrial and marine humic-like fluorophores are produced by marine microbes (e.g., Yamashita et al. 2010; Catalá et al. 2015; Goto et al. 2017; Zhao et al. 2017; Tada et al. 2017), implying that it is difficult to determine the origin of humic-like fluorophores from their spectral characteristics. However, the levels of humic-like fluorophores, including traditionally defined terrestrial and marine humic-like PARAFAC components, in river water are usually high enough to trace these species in coastal environments (e.g., Dorsch and Bidleman 1982; Hayase et al. 1987; Del Castillo et al. 1999; Yamashita et al. 2008). In addition, the levels of humic-like components in sea-ice melt water are generally low due to brine rejection during sea-ice formation (Stedmon et al. 2007, 2011; Müller et al. 2013). Such characteristics of humic-like components indicate that the freshwater end-member(s) of COW can be evaluated using the relationships between humic-like components and salinity. 

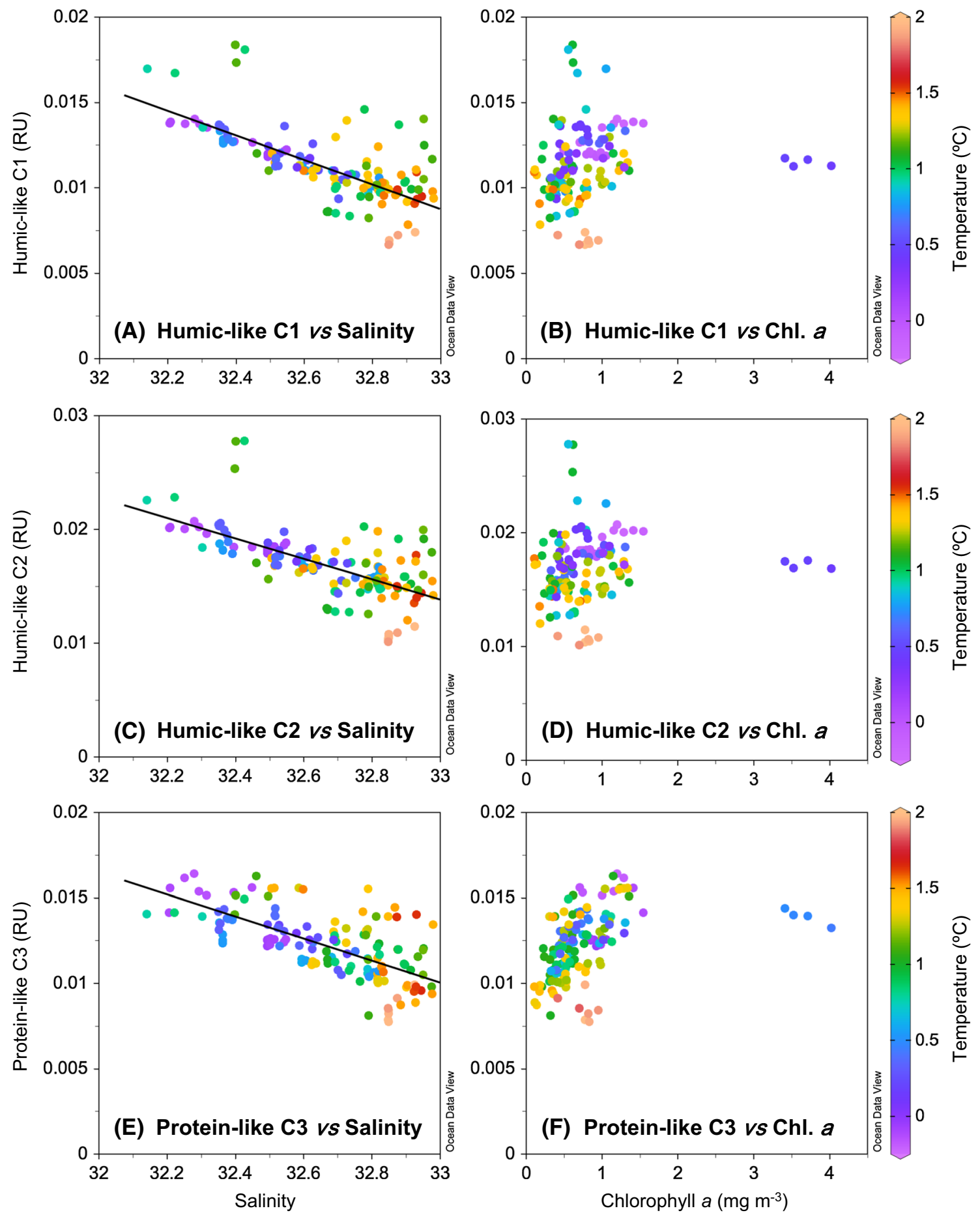

Fig. 7a-f Scatter plots: humic-like C1 (a), humic-like C2 (c), and protein-like C3 (e) versus salinity; humic-like C1 (b), humic-like C2 (d), and protein-like C3 (f) versus the chlorophyll $a$ concentration for

the Coastal Oyashio Water (COW). The water temperature of each sample is indicated by color (refer to the color scales shown next to the plots)

Figure 8 shows the relationships between the humic-like components and salinity for river water, the Amur River estuarine water, and sea-ice melt water in addition to COW. A linear regression line between the individual humic-like components and salinity determined using the COW samples

(Fig. 7a, c) was extrapolated to a salinity of 0 in Fig. 8a, $\mathrm{b}$, respectively. The intercepts of the regressions against fluorescence intensity $(0.25 \pm 0.02$ and $0.31 \pm 0.03$ for $\mathrm{C} 1$ and $\mathrm{C} 2$, respectively) were within the range of fluorescence intensities of humic-like $\mathrm{C} 1$ and $\mathrm{C} 2$ observed for the river 

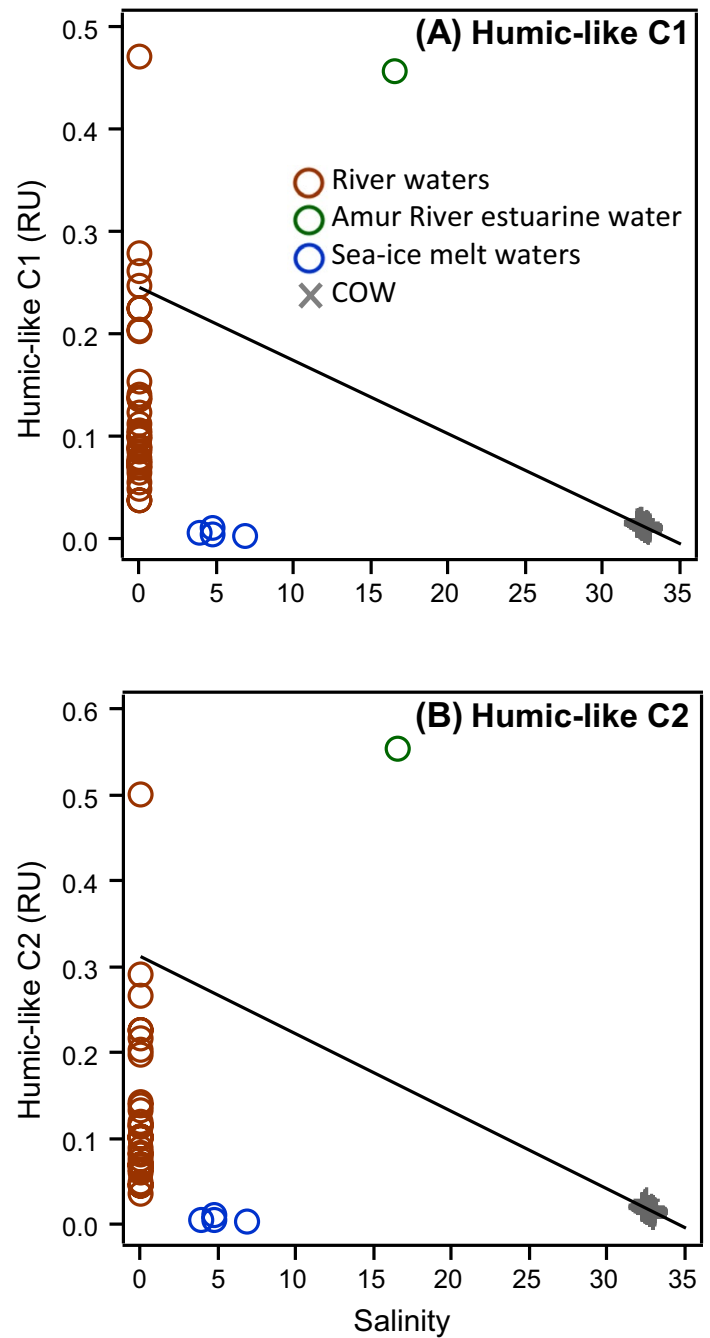

Fig. 8a-b Scatter plots of humic-like C1 (a) and humic-like C2 (b) against salinity for the Coastal Oyashio Water (COW) and its possible end-members (river water, the Amur River estuarine water, and sea-ice melt water). The line in each panel is the linear regression between the humic-like component and salinity determined using the COW samples

water samples. The plots of the sea-ice melt water samples were very different from the regression lines for both humiclike $\mathrm{C} 1$ and $\mathrm{C} 2$. Furthermore, the levels of humic-like $\mathrm{C} 1$ and $\mathrm{C} 2$ in the sea-ice melt water samples were lower than those in COW. These results suggest minimal contributions from sea-ice melt water to COW at the time of sampling. The relatively low $R^{2}$ values for the regression between humic-like components and salinity (Fig. 7) imply that the freshwater from various rivers possibly contributed to the COW observed in this study.

The plots of the Amur River estuarine water collected in September greatly deviated from the regression line between the humic-like components and salinity (Fig. 8a, b), but this relationship may not be directly comparable with that for
COW because the concentration of riverine DOM, including humic-like components, generally increases with increasing river discharge (e.g., Spencer et al. 2009; Mann et al. 2012). The sampling of local rivers in Hokkaido was carried out during the base-flow period of September. Because the hydrographs of the local rivers in Hokkaido show base flow during winter (before the snowmelt), the levels of humiclike components in the local rivers of Hokkaido were possibly comparable between the base-flow periods of September and winter. It should be noted that a high-resolution western North Pacific general circulation model simulated an outflow of COW from the Sea of Okhotsk to the North Pacific through the Kunashiri Strait (and the Nemuro Strait) of approximately $0.5-1.2 \mathrm{~Sv}\left(=10^{6} \mathrm{~m}^{3} \mathrm{~s}^{-1}\right)$ from January to April (Sakamoto et al. 2010). The discharge from the major rivers (i.e., the Tokachi, Kushiro, and Abashiri rivers) in eastern Hokkaido from January to March is on the order of $10^{1}-10^{2} \mathrm{~m}^{3} \mathrm{~s}^{-1}$ for each river. These values suggest that the rivers connected to the Sea of Okhotsk are probably important as freshwater end-members of the COW observed in this study. Otherwise, the local rivers connected to the North Pacific may affect the COW only locally. Further studies are necessary to clarify the river(s) contributing to freshwater end-member(s) of COW.

It is interesting to note that two distinct water masses seemed to contribute less-saline water $(<32.5)$ to COW (Fig. 7a, c). The first water mass featured a lower temperature $\left(<0{ }^{\circ} \mathrm{C}\right)$ and relatively high levels of humic-like components. This water mass plotted near the regression line between humic-like components and salinity and seemed to mainly control the intercept with the humic-like components axis (Fig. 8). Temperatures below $0{ }^{\circ} \mathrm{C}$ and relatively high levels of humic-like components indicated that the river water was mixed with seawater and then cooled in a coastal environment to produce the features of this water mass. The other possible way to form the first water mass is through the influence of sea-ice melt water. A minor contribution from sea-ice melt water in addition to a major contribution from river water can produce moderate-salinity water. Subsequent mixing of moderate- and high-salinity water could form the first water mass. The second water mass was characterized by a relatively high temperature $\left(>0.8^{\circ} \mathrm{C}\right.$; Fig. $\left.7 \mathrm{a}, \mathrm{c}\right)$. This water mass was observed in the surface layer at station A1 just after the passage of the low-pressure system (14-15 March; Fig. 3). The levels of humic-like components in this water mass were highest, and the plots of this water mass deviated slightly from the regression lines between humiclike components (in particular humic-like $\mathrm{C} 1$ ) and salinity. The deviations from the general regression lines imply that different rivers possibly contributed freshwater to the first and second water masses of the COW, respectively, and/or the sea-ice melt water contributions to the first and second water masses of the COW differed. 


\section{Conclusions and implications}

This study is the first to apply the relationship between salinity and humic-like fluorescence to evaluate the distribution of two distinct freshwater end-members in a coastal environment. The novel approach used in this study clarified that river water is the major freshwater end-member of the COW observed in this study. However, the approach could not be used to evaluate the contribution from sea-ice melt water to COW. Because the major freshwater endmember(s) of COW possibly change spatially and temporally, a comprehensive evaluation of the temperature, salinity, and humic-like fluorescence from winter to spring over a wider area (including the Sea of Okhotsk) is necessary. Moreover, the addition of different parameters that can evaluate freshwater end-members, e.g., $\delta^{18} \mathrm{O}$ of water (Oguma et al. 2007, 2008), would enable better evaluation of the spatiotemporal variations in the contributions of river water and sea-ice melt water to COW. In addition, a thorough investigation of the humic-like fluorescence in local rivers in Hokkaido, the Amur River and other rivers in Sakhalin should be carried out to identify the major river(s) that serve as the freshwater end-members of COW.

Two humic-like PARAFAC components, i.e., terrestrial humic-like $\mathrm{C} 1$ and marine humic-like $\mathrm{C} 2$ according to the traditional definitions, seemed to be useful for evaluating the freshwater end-members of COW. Both humic-like components are also produced in the open ocean by marine microbes (e.g., Yamashita et al. 2010; Catalá et al. 2015). Different behaviors of humic-like components (i.e., conservative and nonconservative behavior for terrestrial and marine humic-like components, respectively) were also observed in coastal environments (Yamashita et al. 2008; Cawley et al. 2014). Thus, in future studies, it would be better to use terrestrial humic-like components rather than marine humic-like components to evaluate the freshwater end-members of COW. An in situ fluorescence sensor that has excitation and emission wavelengths close to the peak of the terrestrial humic-like component (e.g., Yamashita et al. 2015b) would also be applicable to such future COW studies.

\footnotetext{
Acknowledgements The authors thank the captain, crew, and scientists on board the R/V Hakuho Maru, P/V Soya, and R/V Professor Khromov for their help with the observations. We are grateful to O. Seki for the collection of some of the river water samples. We also thank three anonymous reviewers for their helpful/constructive comments and suggestions, which helped improve the quality of this manuscript. This research was partially supported by a Grant-in-Aid for Scientific Research (nos. 24121003, JP15H05820, JP15H05818, 16H02930, 17H00775), the Arctic Challenge for Sustainability (ArCS) Project, and the Grant for Joint Research Program of Institute of Low Temperature Science, Hokkaido University.
}

Open Access This article is distributed under the terms of the Creative Commons Attribution 4.0 International License (http://creativeco mmons.org/licenses/by/4.0/), which permits unrestricted use, distribution, and reproduction in any medium, provided you give appropriate credit to the original author(s) and the source, provide a link to the Creative Commons license, and indicate if changes were made.

\section{References}

Ahn YS, Nakamura F, Mizugaki S (2008) Hydrology, suspended sediment dynamics and nutrient loading in Lake Takkobu, a degrading lake ecosystem in Kushiro Mire, northern Japan. Environ Monit Assess 145:267-281. https://doi.org/10.1007/s10661-007-0036-1

Amon RMW, Budéus G, Meon B (2003) Dissolved organic carbon distribution and origin in the Nordic Seas: exchanges with the Arctic Ocean and the North Atlantic. J Geophys Res 108:3221. https://doi.org/10.1029/2002JC001594

Arai K, Wada S, Shimotori K, Omori Y, Hama T (2018) Production and degradation of fluorescent dissolved organic matter derived from bacteria. J Oceanogr 74:39-52. https://doi.org/10.1007/ s10872-017-0436-y

Austnes K, Evans CD, Eliot-Laize C, Naden PS, Old GH (2010) Effects of storm events on mobilisation and in-stream processing of dissolved organic matter (DOM) in a Welsh peatland catchment. Biogeochemistry 99:157-173. https://doi.org/10.1007/s1053 3-009-9399-4

Cao F, Medeiros PM, Miller WL (2016) Optical characterization of dissolved organic matter in the Amazon River plume and the Adjacent Ocean: examining the relative role of mixing, photochemistry, and microbial alterations. Mar Chem 186:178-188. https://doi.org/10.1016/j.marchem.2016.09.007

Catalá TS, Reche I, Fuentes-Lema A, Romera-Castillo C, Nieto-Cid M, Ortega-Retuerta E, Calvo E, Álvarez M, Marrasé C, Stedmon CA, Álvarez-Salgado XA (2015) Turnover time of fluorescent dissolved organic matter in the dark global ocean. Nat Commun 6:5986. https://doi.org/10.1038/ncomms6986

Cawley KM, Yamashita Y, Maie N, Jaffé R (2014) Using optical properties to quantify fringe mangrove inputs to the dissolved organic matter (DOM) pool in a subtropical estuary. Estuaries Coasts 37:399-410. https://doi.org/10.1007/s12237-013-9681-5

Chen RF, Gardner GB (2004) High-resolution measurements of chromophoric dissolved organic matter in the Mississippi and Atchafalaya River plume regions. Mar Chem 89:103-125. https ://doi.org/10.1016/j.marchem.2004.02.026

Chen M, Maie N, Parish K, Jaffé R (2013) Spatial and temporal variability of dissolved organic matter quantity and composition in an oligotrophic subtropical coastal wetland. Biogeochemistry 115:167-183. https://doi.org/10.1007/s10533-013-9826-4

Coble PG (1996) Characterization of marine and terrestrial DOM in seawater using excitation-emission matrix spectroscopy. Mar Chem 51:325-346. https://doi.org/10.1016/0304-4203(95)00062 $-3$

Del Castillo CE, Coble PG, Morell JM, López JM, Corredor JE (1999) Analysis of the optical properties of the Orinoco River plume by absorption and fluorescence spectroscopy. Mar Chem 66:35-51. https://doi.org/10.1016/S0304-4203(99)00023-7

Dorsch JE, Bidleman TF (1982) Natural organics as fluorescent tracers of river-sea mixing. Estuar Coast Shelf Sci 15:701-707. https:// doi.org/10.1016/0272-7714(82)90081-6

Fellman JB, Spencer RGM, Hernes PJ, Edwards RT, D'Amore DV, Hood E (2010) The impact of glacier runoff on the biodegradability and biochemical composition of terrigenous dissolved organic matter in near-shore marine ecosystems. Mar Chem 121:112-122. https://doi.org/10.1016/j.marchem.2010.03.009 
Fellman JB, Petrone KC, Grierson PF (2011) Source, biogeochemical cycling, and fluorescence characteristics of dissolved organic matter in an agro-urban estuary. Limnol Oceanogr 56:243-256. https ://doi.org/10.4319/lo.2011.56.1.0243

Gonçalves-Araujo R, Bracher MA, Granskog A, Azetsu-Scott K, Dodd PA, Stedmon CA (2016) Using fluorescent dissolved organic matter to trace and distinguish the origin of Arctic surface waters. Sci Rep 6:33978. https://doi.org/10.1038/srep33978

Goto S, Tada Y, Suzuki K, Yamashita Y (2017) Production and reutilization of fluorescent dissolved organic matter by a marine bacterial strain, Alteromonas macleodii. Front Microbiol 8:507. https ://doi.org/10.3389/fmicb.2017.00507

Hanawa K, Mitsudera H (1986) Variation of water system distribution in the Sanriku coastal area. J Oceanogr Soc Jpn 42:435-446

Hattori-Saito A, Nishoka J, Ono T, McKay RML, Suzuki K (2010) Iron deficiency in micro-sized diatoms in the Oyashio region of the western subarctic Pacific during spring. J Oceanogr 66:105-115. https://doi.org/10.1007/s10872-010-0009-9

Hayase K, Yamamoto M, Nakazawa I, Tsubota H (1987) Behavior of natural fluorescence in Sagami Bay and Tokyo Bay, Japan-vertical and lateral distributions. Mar Chem 20:265-276. https://doi. org/10.1016/0304-4203(87)90077-6

Isoda Y, Kuroda H, Myousyo T, Honda S (2003) Hydrographic feature of coastal Oyashio and its seasonal variation. Bull Coast Oceanogr 41:5-12 (in Japanese with English abstract)

Joyce TM (1989) On in situ “calibration”' of shipboard ADCPs. J Atmos Ocean Technol 6:169-172

Kanna N, Toyota T, Nishioka J (2014) Iron and macro-nutrient concentrations in sea ice and their impact on the nutritional status of surface waters in the southern Okhotsk Sea. Prog Oceanogr 126:44-57. https://doi.org/10.1016/j.pocean.2014.04.012

Kono T (1997) Modification of the Oyashio water in the Hokkaido and Tohoku areas. Deep-Sea Res II 44:669-688. https://doi. org/10.1016/S0967-0637(96)00108-2

Kono T, Sato M (2010) A mixing analysis of surface water in the Oyashio region: its implications and application to variations of the spring bloom. Deep-Sea Res II 57:1595-1607. https://doi. org/10.1016/j.dsr2.2010.03.004

Kono T, Foreman M, Chandler P, Kashiwai M (2004) Coastal Oyashio South of Hokkaido, Japan. J Phys Oceanogr 34:1477-1494

Kusaka A, Ono T, Azumaya T, Kasai H, Oguma S, Kawasaki Y, Hirakawa K (2009) Seasonal variations of oceanographic conditions in the continental shelf area off the eastern Pacific coast of Hokkaido, Japan (in Japanese with English abstract). Umi Kenkyu 48:135-156

Lawaetz AJ, Stedmon CA (2009) Fluorescence intensity calibration using Raman scatter peak of water. Appl Spectrosc 6:936-940. https://doi.org/10.1366/000370209788964548

Maie N, Sekiguchi S, Watanabe A, Tsutsuki K, Yamashita Y, Melling L, Cawley KM, Shima E, Jaffé R (2014) Dissolved organic matter dynamics in the oligo/meso-haline zone of wetland-influenced coastal rivers. J Sea Res 91:58-69. https://doi.org/10.1016/j.seare s.2014.02.016

Mann PJ, Davydova A, Zimov N, Spencer RGM, Davydov S, Bulygina E, Zimov S, Holmes RM (2012) Controls on the composition and lability of dissolved organic matter in Siberia's Kolyma River basin. J Geophys Res 117:G01028. https://doi.org/10.1029/2011J G001798

McKnight DM, Boyer EW, Westerhoff PK, Doran PT, Kulbe T, Anderson DT (2001) Spectrofluorometric characterization of dissolved organic matter for indication of precursor organic material and aromaticity. Limnol Oceanogr 46:38-48. https://doi.org/10.4319/ lo.2001.46.1.0038

Mizuta G, Fukamachi Y, Ohshima KI, Wakatsuchi M (2003) Structure and seasonal variability of the East Sakhalin current. J Phys Oceanogr 33:2430-2445
Moran MA, Sheldon WM Jr, Zepp RG (2000) Carbon loss and optical property changes during long-term photochemical and biological degradation of estuarine dissolved organic matter. Limnol Oceanogr 45:1254-1264. https://doi.org/10.4319/lo.2000.45.6.1254

Müller S, Vähätalo AV, Stedmon CA, Granskog MA, Norman L, Aslam SN (2013) Selective incorporation of dissolved organic matter (DOM) during sea ice formation. Mar Chem 155:148-157. https ://doi.org/10.1016/j.marchem.2013.06.008

Muneoka K, Okazawa H, Tsuji O, Kimura M (2012) The nitrate nitrogen concentration in river water and the proportion of cropland in the Tokachi River watershed. Int J Environ Rural Dev 3-2:193-199

Nakayama Y, Kuma K, Fujita S, Sugie K, Ikeda T (2010) Temporal variability and bioavailability of iron and other nutrients during the spring phytoplankton bloom in the Oyashio region. Deep-Sea Res II 57:1618-1629. https://doi.org/10.1016/j.dsr2.2010.03.006

Nishioka J, Ono T, Saito H, Sakaoka K, Yoshimura T (2011) Oceanic iron supply mechanisms which support the spring diatom bloom in the Oyashio region, western subarctic Pacific. J Geophys Res 116:C02021. https://doi.org/10.1029/2010JC006321

Nishioka J, Nakatsuka T, Ono K, Volkov YN, Scherbinin A, Shiraiwa $\mathrm{T}$ (2014) Quantitative evaluation of iron transport processes in the Sea of Okhotsk. Prog Oceanogr 126:180-193. https://doi. org/10.1016/j.pocean.2014.04.011

Oguma S, Kawasaki Y, Azumaya T (2007) Water mass variation process in the Nemuro Strait during spring and autumn. Umi Kenkyu 16:361-374

Oguma S, Ono T, Kusaka A, Kasai H, Kawasaki Y, Azumaya T (2008) Isotopic tracers for water masses in the coastal region of eastern Hokkaido. J Oceanogr 54:525-539. https://doi.org/10.1007/s1087 2-008-0044-y

Ohtani K (1971) Studies on the change of the hydrographic conditions in the Funka Bay. II. Characteristics of the water occupying the Funka Bay (in Japanese with English abstract). Bull Fac Fish Hokkaido Univ 22:58-66

Ohtani K (1989) The role of the Sea of Okhotsk in the formation of the Oyashio water. Umi Sora 65:63-83 (in Japanese with English abstract)

Qiu B (2001) Kuroshio and Oyashio currents. Encyclopedia of ocean sciences. Academic, New York, pp 1413-1425

Romera-Castillo C, Sarmento H, Álvarez-Salgado XA, Gasol JM, Marrasé C (2011) Net production and consumption of fluorescent colored dissolved organic matter by natural bacterial assemblages growing on marine phytoplankton exudates. Appl Environ Microbiol 77:7490-7498. https://doi.org/10.1128/AEM.00200-11

Rosa AL, Isoda Y, Uehara K, Aiki T (2007) Seasonal variations of water system distribution and flow patterns in the southern sea area of Hokkaido, Japan. J Oceanogr 63:573-588. https://doi. org/10.1007/s10872-007-0051-4

Saito H, Tsuda A, Kasai H (2002) Nutrient and plankton dynamics in the Oyashio region of the western subarctic Pacific Ocean. Deep-Sea Res II 49:5463-5486. https://doi.org/10.1016/S0967 -0645(02)00204-7

Sakamoto K, Tsujino H, Nishikawa S, Nakano H, Motoi T (2010) Dynamics of the Coastal Oyashio and its seasonal variation in a high-resolution Western North Pacific Ocean Model. J Phys Oceanogr 40:1283-1301. https://doi.org/10.1175/2010JPO4307.1

Spencer RGM, Aiken GR, Butler KD, Dornblaser MM, Striegl RG, Hernes PJ (2009) Utilizing chromophoric dissolved organic matter measurements to derive export and reactivity of dissolved organic carbon exported to the Arctic Ocean: a case study of the Yukon River, Alaska. Geophys Res Lett 36:L06401. https://doi. org/10.1029/2008GL036831

Stedmon CA, Bro R (2008) Characterizing dissolved organic matter fluorescence with parallel factor analysis: a tutorial. 
Limnol Oceanogr Methods 6:572-579. https://doi.org/10.4319/ lom.2008.6.572

Stedmon CA, Markager S, Bro R (2003) Tracing dissolved organic matter in aquatic environments using a new approach to fluorescence spectroscopy. Mar Chem 82:239-254. https://doi.org/10.1016/ S0304-4203(03)00072-0

Stedmon CA, Thomas DN, Granskog M, Kaartokallio H, Papadimitriou S, Kuosa H (2007) Characteristics of dissolved organic matter in Baltic coastal sea ice: allochthonous or autochthonous origins? Environ Sci Technol 41:7273-7279. https://doi.org/10.1021/es071 $210 \mathrm{f}$

Stedmon CA, Thomas DN, Papadimitriou S, Granskog MA, Dieckmann GS (2011) Using fluorescence to characterize dissolved organic matter in Antarctic sea ice brines. J Geophys Res 116:G03027. https://doi.org/10.1029/2011JG001716

Tada Y, Nakaya R, Goto S, Yamashita Y, Suzuki K (2017) Distinct bacterial community and diversity shifts after phytoplankton derived dissolved organic matter addition in a coastal environment. J Exp Mar Biol Ecol 495:119-128. https://doi.org/10.1016/j.jembe .2017 .06 .006

Tanaka K, Kuma K, Hamasaki K, Yamashita Y (2014) Accumulation of humic-like fluorescent dissolved organic matter in the Japan Sea. Sci Rep 4:5292. https://doi.org/10.1038/srep05292

Tanaka K, Takesue N, Nishioka J, Kondo Y, Ooki A, Kuma K, Hirawake T, Yamashita Y (2016) The conservative behavior of dissolved organic carbon in surface waters of the southern Chukchi Sea, Arctic Ocean, during early summer. Sci Rep 6:34123. https://doi.org/10.1038/srep34123

Vähätalo AV, Wetzel RG (2004) Photochemical and microbial decomposition of chromophoric dissolved organic matter during long (months-years) exposures. Mar Chem 89:313-326. https://doi. org/10.1016/j.marchem.2004.03.010

Vodacek A, Blough NV, DeGrandpre MD, Michael D, Peltzer ET, Nelson RK (1997) Seasonal variation of CDOM and DOC in the Middle Atlantic Bight: terrestrial inputs and photooxidation. Limnol Oceanogr 42:674-686. https://doi.org/10.4319/lo.1997.42.4.0674

Walker SA, Amon RMW, Stedmon C, Duan S, Louchouarn P (2009) The use of PARAFAC modeling to trace terrestrial dissolved organic matter and fingerprint water masses in coastal Canadian Arctic surface waters. J Geophys Res 114:G00F06. https://doi. org/10.1029/2009jg000990

Walker SA, Amon RMW, Stedmon CA (2013) Variations in high-latitude riverine fluorescent dissolved organic matter: a comparison of large Arctic rivers. J Geophs Res 118:1689-1702. https://doi. org/10.1002/2013JG002320

Welschmeyer NA (1994) Fluorometric analysis of chlorophyll $a$ in the presence of chlorophyll $b$ and phaeopigments. Limnol Oceanogr 39:1985-1992. https://doi.org/10.4319/lo.1994.39.8.1985

Williams CJ, Yamashita Y, Wilson HF, Jaffé R, Xenopoulos MA (2010) Unraveling the role of land use and microbial activity in shaping dissolved organic matter characteristics in stream ecosystems.
Limnol Oceanogr 55:1159-1171. https://doi.org/10.4319/ lo.2010.55.3.1159

Woli KP, Hayakawa A, Kuramochi K, Hatano R (2008) Assessment of river water quality during snowmelt and base flow periods in two catchment areas with different land use. Environ Monit Assess 137:251-260. https://doi.org/10.1007/s10661-007-9757-4

Yamamoto-Kawai M, McLaughlin FA, Carmack EC, Nishino S, Shimada K, Kurita N (2009) Surface freshening of the Canada Basin, 2003-2007: river runoff versus sea ice meltwater. J Geophys Res 114:C00A05. https://doi.org/10.1029/2008jc005000

Yamashita Y, Tanoue E (2003) Chemical characterization of proteinlike fluorophores in DOM in relation to aromatic amino acids. Mar Chem 82:255-271. https://doi.org/10.1016/S0304-4203(03)00073 $-2$

Yamashita Y, Jaffé R, Maie N, Tanoue E (2008) Assessing the dynamics of dissolved organic matter (DOM) in coastal environments by excitation emission matrix fluorescence and parallel factor analysis (EEM-PARAFAC). Limnol Oceanogr 53:1900-1908. https:// doi.org/10.4319/lo.2008.53.5.1900

Yamashita Y, Cory RM, Nishioka J, Kuma K, Tanoue E, Jaffé R (2010) Fluorescence characteristics of dissolved organic matter in the deep waters of the Okhotsk Sea and the northwestern North Pacific Ocean. Deep Sea Res Part II 57:1478-1488. https://doi. org/10.1016/j.dsr2.2010.02.016

Yamashita Y, Panton A, Mahaffey C, Jaffé R (2011) Assessing the spatial and temporal variability of dissolved organic matter in Liverpool Bay using excitation-emission matrix fluorescence and parallel factor analysis. Ocean Dyn 61:569-579. https://doi. org/10.1007/s10236-010-0365-4

Yamashita Y, Nosaka Y, Suzuki K, Ogawa H, Takahashi K, Saito $\mathrm{H}$ (2013) Photobleaching as a factor controlling spectral characteristics of chromophoric dissolved organic matter in open ocean. Biogeoscience 10:7207-7217. https://doi.org/10.5194/ bg-10-7207-2013

Yamashita Y, Fichot CG, Shen Y, Jaffé R, Benner R (2015a) Linkages among fluorescent dissolved organic matter, dissolved amino acids and lignin-derived phenols in a river-influenced ocean margin. Front Mar Sci 2:92. https://doi.org/10.3389/fmars.2015.00092

Yamashita Y, Lu C-J, Ogawa H, Nishioka J, Obata H, Saito H (2015b) Application of an in situ fluorometer to determine the distribution of fluorescent organic matter in the open ocean. Mar Chem 177:298-305. https://doi.org/10.1016/j.marchem.2015.06.025

Yasuda I, Okuda K, Hirai M (1992) Evolution of a Kuroshio warmcore ring-variability of the hydrographic structure. Deep-Sea Res 39(Suppl 1):S131-S161. https://doi.org/10.1016/S0198 -0149(11)80009-9

Zhao Z, Gonsior M, Luek J, Timko S, Ianiri H, Hertkorn N, SchmittKopplin P, Fang X, Zeng Q, Jiao N, Chen F (2017) Picocyanobacteria and deep-ocean fluorescent dissolved organic matter share similar optical properties. Nat Commun 8:15284. https:// doi.org/10.1038/ncomms15284 